\title{
Developing An Online Shopping Value Framework For Consumers Of Non-Store Fashion Brands
}

Nobukhosi Dlodlo, Vaal University of Technology, South Africa

\begin{abstract}
The explosion of the Internet has considerably transformed the fashion industry, by providing a substitute for traditional retail marketing formats. As such, the theory on customer value has taken pre-eminence in determining consumers' behavioural intentions. The main objective of this study was to examine the possible existence of relationships between consumer perceived value, attitudes and the related e-purchase consequence variable. The study followed a quantitative survey approach in which 206 experienced Internet users of online shopping in South Africa were surveyed. Data were analysed through Principal Component Analysis using Varimax rotation, parametric correlation tests and simple regression analysis. Three dimensions were extracted, namely: utilitarian value $(\alpha=.852)$, hedonic value $(\alpha=.901)$ and social engagement value $(\alpha=.925)$ in order of the rankings on the mean score results. Moreover, the Pearson correlation results indicated that online shopping value dimensions positively influenced attitude and consequently, e-purchase intentions among shoppers. Furthermore, regression analysis results showed that attitude played an important moderating role between value and e-purchase intentions. The variables investigated in this study constitute a central differentiation factor which impacts on attitude, intention to purchase as well as the willingness to visit the website and share the experience with others. The study is important in that, at the micro-level, e-retailers can tailor the identified dimensions towards improving the shopping experience among specific online market segments. At the macro-level, identifying the online shopping value dimensions would provide fashion marketers with a basis for developing an inclusive marketing differentiation strategy for their non-store brands.
\end{abstract}

Keywords: Non-Store Fashion Brands, Online Shopping Value, Utilitarian, Hedonic, Engagement

\section{INTRODUCTION}

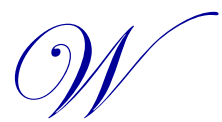

ithin emerging markets, fashion is among the sectors that gains the most from global trade liberalisation and provides job opportunities for unskilled labour in both developed and developing countries (Levy \& Weitz, 2009). In South Africa, fashion forms part of an important industry which is heavily supported by fiscal authorities as part of their economic development programme (Christianson, 2004). Notwithstanding this, the local retail clothing industry's turnover was estimated at approximately R50 billion per annum a decade ago (Makholwa, 2011) and experienced a compounded 8.3 percent annual growth rate between 2004 and 2010 (Research \& Markets, 2010). As of 2010, the textile, clothing, footwear and leather goods industry contributed 19.76 per cent of the total retail revenue with the adult men's and women's clothing industry bringing in the highest sales of all retail commodities (Statistics South Africa, 2010).

Findings from the South African Press Association (SAPA, 2012) indicate that the total value of online fashion retailing sales alone was estimated to be at R 2.26 Billion in 2012, which contributes 0.36 per cent of total South African retail. The MasterCard Worldwide Online Shopping Survey reported that the proportion of South African Internet users shopping online grew to 58 per cent in 2012, up from 53 per cent in 2010 and 44 per cent in 2009 (Planting, 2012). Furthermore, the arrival of PayPal, an online payments system, in 2010 has helped to 
encourage growth within the e-commerce market. Relatedly, economic globalisation, driven by deregulation and the pervasive use of information technologies has opened up new inescapable channels for fashion retailers (Moodley, 2003). It may therefore be inferred that the Internet has become a key enabler for a networked retail economy.

Consumers are becoming more comfortable online due to social media access, Internet banking access as well as widespread expectations to conduct a large portion of business matters online. In terms of fashion e-tailing, shoppers cite reasons such as greater convenience (no queues, parking, jostling crowds, time-saving), more affordable pricing, the ability to purchase unique clothing brands that few others possess, in addition to greater variety, in favour of online shopping (Okonkwo, 2009). Typically, online customers can more easily compare alternatives across different fashion websites since a competing offer is just a few clicks away on the Internet (Childers et al., 2001). As such, recent studies show that there may be systematic differences in customer attitudes and behaviour for fashion products and services chosen online with specific brand names delivering a higher impact online than offline (Balabanis, Reynolds \& Simintiras, 2006).

The results of previous research conducted by Siddiqui et al. (2003) and Seringhaus (2005) which focused on online fashion retailing demonstrated that customers desire website experiences that are engaging, memorable and interactive. Rowley (2009) further suggested that fashion websites that offer social interaction, two-way communication and a personalised relationship with the brand are likely to attract enhanced attention from online consumers. In view of this notion, fashion retailers can use Web 2.0 technologies to create immersing online store environments (Okonkwo, 2009). Other retailers have created visual tours of their exclusive non-store brands through social networks such as Facebook and Twitter. Such interactive and collaborative aspects are phenomenal towards providing ample opportunities for increasing the value that customers derive from the online shopping experience (McKinsey, 2008). As observed by Hallem and Barth (2011), success of the Internet as a commercial platform is the result of the medium's ability to create and deliver superior value to the customer. This form of value that is delivered online provides fashion retailers with a differentiation strategy (Strydom, 2011). Therefore, it is important to understand those customer value perceptions which precipitate the totality of online fashion brands as irreplaceable among shoppers.

The Internet has transformed the fashion value chain, with an upward trend towards growing numbers of fashion shoppers who are patronising online stores (Cheng, Wang, Lin \& Vivek, 2009). While consumers are becoming more informed and learning the value of cutting out the middle man, it has become necessary for marketers to develop an enhanced appreciation of the value of the non-store brand, which is what consumers actually pay for. Indeed, from a retailing perspective, De Sarbo, Ebbes, Fong and Snow (2010) noted that when retailers satisfy people-based needs, they are delivering value, which puts them in a much stronger position in the long term. As such, individual organisations can use this knowledge to match their product and service offerings with customer demands. For the fashion retailers, this could help to clarify the value desired and possibly expand website visitation (Van der Heijden, Verhagen \& Creemers, 2003), length of stay (Okonkwo, 2009) and online expenditure to yield maximisation (Siddiqui et al., 2003; Goldsmith \& Goldsmith, 2002).

\section{THE SCOPE OF NON-STORE FASHION BRANDS}

According to Okonkwo (2009), a fashion brand is a list of notable fashion designers sorted by their nationality or place of birth. It includes designers of haute couture and ready-to-wear clothing. The current study was restricted to several upstart online fashion retailers representing a number of South African designers and local brands. Planting (2012) highlights that the most prominent examples of such entrants include inter alia; (1) Zando which boasts 200000 unique visitors a month and growth that outpaces traditional retailers, (2) Lushberry, popular for its referral-based discount programmes targeting high-income female consumers, (3) Sassychic known for its personalised and attentive online service (4) 36Boutique, a member of the MIH e-commerce group and (4) Spree, a subdivision of Media24 that is based on the 'shoppable magazine' concept, meaning that the collection is carefully curated and styled by in-house experts. The entrepreneurs are taking full advantage of the global visibility of their brands (Makholwa, 2011), rent-free platforms (SAPA, 2012) as well as association of their unique brands with retail stores (Planting, 2012). 
Selling fashion brands online requires a different set of strategies and tools than selling and branding any other commodity (Siddiqui et al., 2003). This may be attributed to the fact that fashion brands thrive on combining emotion, image and perception (Rowley, 2009). In light of this fact, the challenge pertains to how these characteristics of perceptibility and online multi-sensory experiences may be transformed into customer value using Internet technologies (Seringhaus, 2005). Although a trajectory has been observed in the number of companies that are attempting to support their marketing strategies using interactive platforms, online consumers still have the choice regarding which websites to spend their time on or which virtual brand communities to participate in while not others (Seraj, 2012). Since some online fashion stores seem to draw high traffic levels than others (Strydom, 2011), there remains an undoubted value perception difference between successful and failing online fashion brands.

\section{UNDERLYING THEORETICAL CONTEXT AND HYPOTHESES DEVELOPMENT}

The current study is based on two major categories of theories namely (1) the theory of planned behaviour and (2) customer value theories.

\section{Theory of Reasoned Action}

The Theory of Reasoned Action (TRA) (Ajzen, 1989) is a model for predicting behavioural action through assessing attitude and subjective norms as immediate constructs of determination. Behavioural intention measures a person's relative strength or intention to perform a particular behaviour while attitude is defined as the individual's salient beliefs regarding the perceived outcomes of performing that specific behaviour (Kotler \& Keller, 2012). Subjective norm is seen as a combination of perceived expectations from relevant individuals or groups (reference groups) along with intentions to comply with these expectations. Therefore, in simple terms, TRA assumes that a person's volitional (voluntary) behaviour is predicted by his/her attitude toward that behaviour and how other people would view them if they performed the behaviour in question (Grewal \& Levy, 2010). Therefore, a person's attitude, combined with subjective norms, forms his behavioural intention. In the current study, attitude towards online nonstore brands will be evaluated as they pose distinct marketing dynamics from those brands that are also available within brick and mortar stores. In addition, the TRA assumes that purchase intentions are a proximal cause of online purchase activity (Rowley, 2009). Therefore, since intentions represent motivational components of behaviour, this variable will be used in this particular study to demonstrate the degree of conscious effort that consumers will exert in order to make purchases of fashion brands through online platforms.

\section{Customer Value Theories}

A consumer's behaviour is a result of motives, attitudes and values and may manifest into purchase and consumption behaviour. Value is one of the most powerful forces in the marketplace to understand consumer behaviour (Zeithaml, 1988; Holbrook, 1999). As such, customer value originates from the confrontation between what the customer receives (quality, benefits, worth, utilities) and what he or she gives up (price, sacrifices) to acquire those benefits (Chen \& Dubinsky, 2003). Value plays an important role in predicting customers' product choices and future re-purchase intentions of non-store brands. Thus, value judgment creates consumer preference and this consumer preference increases behavioural intention to participate in various shopping processes (Cronin, Brady \& Hult, 2000; Overby \& Lee, 2006). Drawing concepts from the field of cognitive psychology the concept of shopping value came from the research conducted mainly in the field of micro-economics and classical decision theory (Holbrook \& Hirschman, 1982). However, Westbrook and Black (1985) posited that some shopping motives are utilitarian in nature whereas others are hedonic. Therefore, in order to demonstrate the totality of the online shopping experience, Seraj and Toker (2012) suggested that web 2.0 fosters the benefits of building online communities leading to the development of intellectual value that is co-created through customer engagement. These shopping value dimensions will be discussed below.

\section{Utilitarian Value}

Utilitarianism is described as ergic and task related meaning that a product is purchased efficiently and rationally (Babin, Darden \& Griffin, 1994). it is a value construct that is related to necessity rather than to pleasure seeking and is often described in terms commonly used to evaluate technology performance (e.g. usefulness, 
accomplishment) (Chaudhuri, Aboulnasr, \& Ligas 2010; Holbrook \& Hirschman, 1982). Since online shopping is compared to a task and its value weighted on its success or online order completion, therefore, perceived utilitarian value is determined by how much of the consumption needs that prompt the shopping experience to be met ( $\mathrm{Li}, \mathrm{Kim}$ \& Lee, 2009). Therefore, utilitarian purchasing behaviour is more logical and directly related to the actual transactions (Rintamäki et al., 2006). As such, utilitarian value captures the functional qualities of the online retail website in being able to exhibit relatively higher levels of technical prowess (Li \& Zhang, 2002); the benefit associated with gathering relevant fashion information from the website (Childers, Cristopher, Peck, \& Carson, 2001) and the ability of the non-store brands to either meet or exceed pre-defined performance levels (Byun \& Mann, 2011).

In addition, an effective website design which provides fast, uncluttered and easy-to-navigate service so that consumers attempting to shop online find the site easy to use and simple in content, context and infrastructure, is welcome (Burke, 2002). Once a value-benefit is professed from online fashion brands, then it may be expected that consumers will develop favourable attitudes and Internet shopping preferences, which in turn, will predict future patronage intent (Mathwick, Malhotra \& Rigdon, 2002). In this regard, the following hypothesis is formulated for the study:

$\mathbf{H}_{1:}$ Utilitarian value of online fashion brands is positively associated with attitude.

\section{Hedonic Value}

A group of researchers have analysed shopping from different perspectives by focusing on the emotional and irrational aspects of individual buying behaviour. Dichter (1947) pioneered this research tradition, which is known as motivation research (Sheth et al., 1991). The basic premise of this research tradition is that consumers make product or brand choices for emotional reasons deeply rooted in their psychology. As such, hedonism is the festive, ludic or even epicurean side of shopping (Childers et al., 2001). It is related to fun and playfulness rather than to task completion or goal orientation as is the case with utilitarianism (Rintamäki et al., 2006). As such, hedonic value reflects the experiential side of online shopping, comprising pleasure, curiosity, fantasy and escapism (Scarpi, 2012). For example, fashion shoppers could derive hedonism when browsing through online catalogues, enjoying showroom videos and also while personalising a wide array of clothing items.

Previous studies have identified and included fun, pleasure, recreation, freedom, fantasy, increased arousal, heightened involvement, new information and escape from reality as hedonic shopping value elements (Kazakeviciute \& Banyte, 2012; Babin et al., 1994). Evidently, recreational shoppers, namely those who enjoy shopping as a leisure activity, have a more positive attitude toward web retailing (Chen \& Dubinsky, 2003). Consequently, there is a positive relationship between the experience of 'flow' and the hedonic value of online shopping experiences subsequently mutating into positive attitudes towards non-store fashion brands (Okonkwo, 2009). It is against the aforementioned discourse that the following hypothesis is formulated for the study:

$\mathbf{H}_{2:}$ Hedonic value of online fashion brands is positively associated with attitude.

\section{Engagement Value}

Kazakeviciute and Banyte, (2012) suggested that shopping gratification includes the opportunity for social interactions with friends, family or even strangers and the sensory stimulation such as exchanging new information about upcoming trends and fashion. Within the online context, the significance of online customer engagement through chat-rooms, blogs and ratings is appreciated in this regard (Goldsmith \& Goldsmith, 2002). This development is made possible by customers playing a role through contributing, customising, rating, distributing and interpreting non-store brand information through the Internet (Humphreys, 2010). The greater proportion of the content allows the consumer to co-create his/her personalised online shopping experience (Seraj, 2012).

Seringhaus (2005) argued that Web 2.0 has been a source for the explosion of prosumption through various channels such as wikis and blogs which contain updated articles written by users on various fashion news and topics. The term 'prosumer' is a portmanteau coined by Toffler (1980) to refer to the metamorphosing roles between 
producer and consumer market segments on digital platforms. Seemingly, social networking sites (Boyd \& Ellison, 2007) such as Facebook or MySpace have also been used by online consumers where both textual and visual information is co-created and shared on a public domain. Other platforms include microblogs such as Twitter and weblogs where ideas, interpretations and insights are prosumed by the authors and their followers (Seraj \& Toker, 2012). Relatedly, online shopping websites allow for consumers to provide feedback about their shopping experience, creating word-of-mouth and hence, leaving traces of their buying habits (Kim \& Forsythe, 2008). As such, it is not only the sharing of the original content that brings the added value, but also the added comments and opinions to the disclosed message or visual item, contributes to the generated content and the totality becomes an invaluable asset or artefact of an online brand community (Seraj \& Toker, 2012).

Taking into consideration the premises for collaborations such as two-way communication, social presence and active participation in brand communities, it can already be established that the emergence of new technology and the increasing engagement of consumers as a consequence thereof, paves the way for companies and consumers to engage in co-creating value (Humphreys, 2010). As this information is acquired and learned by the consumers, this will lead to the formation of specific attitudes towards certain brands. According to Kotler and Keller (2012), consumers' overall attitude toward a brand is the basis of brand associations as well as the core of many conceptualisations of purchase intentions. Similarly, as evidenced by the direct relationship between customer value and attitude (Swait \& Sweeney, 2000), it may be expected that consumers who realise high social engagement value from an online shopping experience will develop positive attitudes towards non-store brands than those who perceive low value from the same. In this regard, the following hypothesis is formulated for the study:

$\mathbf{H}_{3 \text { : }}$ Engagement value of online fashion brands is positively associated with attitude.

Attitude And E-Purchase Intentions

An important driver of brand success is its ability to generate positive emotional and cognitive evaluations among its consumers, collectively described as attitudes (Kotler \& Keller, 2012). As such, there is long-standing evidence around the attitude construct linking 'cognitive' to 'affective' to 'conative' evaluations with the later incorporating behavioural intentions (Grewal \& Levy, 2010). Therefore, where positive attitudes are achieved, there is potential for fulfilled consumers to re-purchase and subject to context, further pay higher prices relative to comparable product offerings (Levy \& Weitz, 2009).

Relatedly, the purchase intention construct encompasses measures of ongoing engagement with the brand through repeat or additional purchases that is likewise, influenced by consumer thoughts, values and emotions (Kotler \& Keller, 2012). The relationship between attitude and purchase intentions is further expounded in the theory of planned behaviour (Ajzen, 1989) which concedes that the more favourable the attitude and subjective norm with respect to behaviour; hence the stronger should be an individual's intention to perform the behaviour under consideration. Studies of Koo and Ju (2008) pointed to a mediating role of the attitude variable between consumer value and purchase intention, thus offering comparability to the work of Morris et al. (2002). Parallels exist in the model presented by O'Cass and Choy (2008) from the luxury fashion retailing arena where involvementdriven values link to attitudes towards the brand and in turn, willingness to pay higher prices. As such, the background provided by previous empirical studies lends credence to the formulation of the following hypothesis in this study:

$\mathbf{H}_{4}$ : Attitude towards non-store fashion brands is positively associated with e-purchase intentions.

Figure 1 depicts the Online Shopping Value (OSV) framework that is proposed for the current study. Given that e-tailers present an extended form of fashion brand marketing, the perceived value of online retailing technology would be expected to be positively associated with attitude and subsequently intentions to purchase online, non-store brands. Therefore, a positive, predictive relationship is expected between utilitarian value, hedonic value and engagement value constructs with attitude towards the usage of online technology for fashion purchases. In addition, the attitude (ATT) variable is expected to perform as a fundamental determinant of patrons' future intentions to participate in online buying behaviour among South African fashion consumers. 


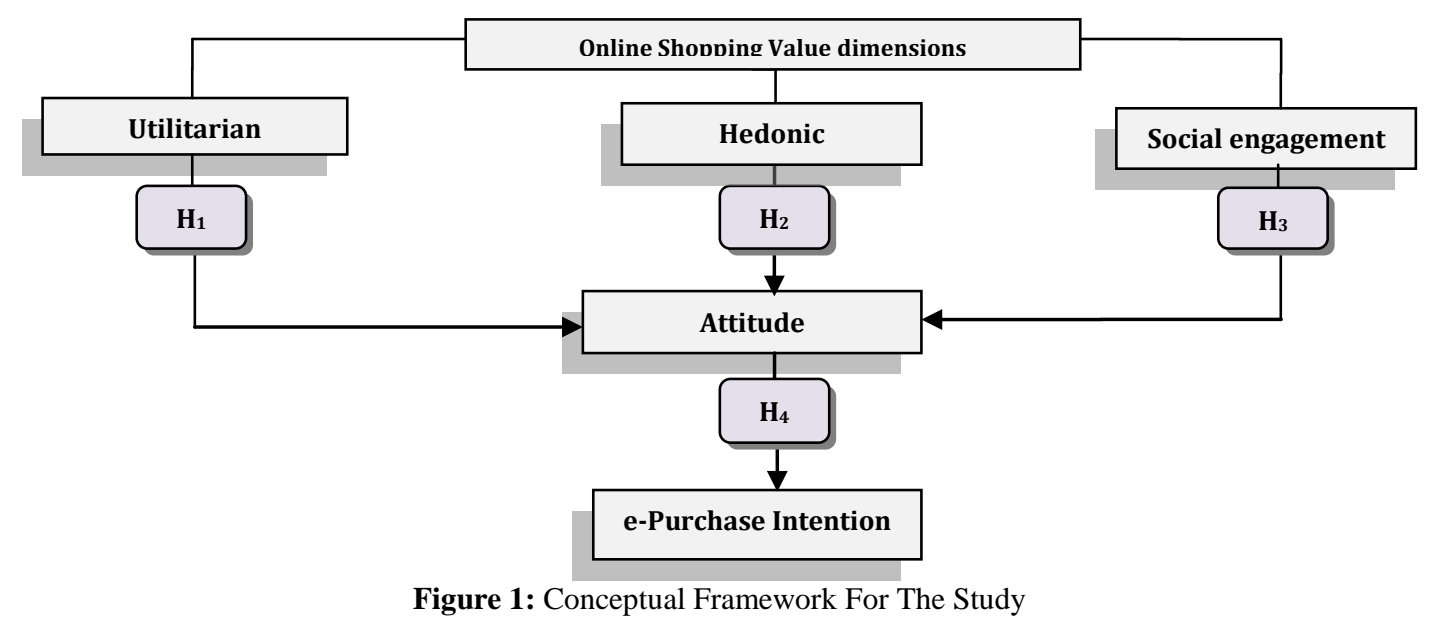

\section{PROBLEM STATEMENT}

It has been established that there is high growth in the market for non-store fashion brands, with the Internet transforming as a substitute for traditional retail marketing formats (Seraj, 2012). Moreover, the high fashion retail sector demonstrates signs of enormous competitiveness (Sweeney \& Soutar, 2001) and invariably contributes significantly to the South African economy (Statistics South Africa, 2010). Nevertheless, although a trajectory in the high growth rate in online retailing may be expected to continue, the current slow economic environment creates challenges for retailers to ensure that customers perceive sufficient value from the online fashion brands to compensate for the high prices (Levy \& Weitz, 2009).

While taking a coup d'oeil into researches based on a South African sample, a paucity of studies on customer value exists. Bick, Brown and Abratt (2004) conducted research on customer perceived value in retail banking in South Africa. Terblanche and Boshoff (2010) investigated relationships between perceived value, satisfaction and loyalty among consumers in the South African fast food industry whereas Ali (2008) surveyed the perceived value of restaurant leisure services around Pretoria. Similarly, Strydom (2011) developed a multidimensional model for the high fashion retail industry while Seymour (2012) evaluated value dimensions within the context of scuba diving tourists at a marine destination off the Sodwana Bay in the country's coastal region. However, no study has researched the salient dimensions of shopping value within an online fashion retail setting in South Africa. Relatedly, there have been no scholarly attempts that have been made to establish the existence of path relationships between online customer value dimensions with attitude and purchase intentions.

Researchers have identified a link between providing superior value, customer satisfaction and purchase intentions albeit within traditional shopping experiences (Gallarza \& Saura, 2006; Sweeney \& Soutar, 2001) which emphasises the necessity for further research on online based customer value. Developing such a framework will aid in understanding the underlying dimensions of online shopping value in the fashion industry and will better position the fashion retailer to provide customer value that will consequently lead to customer satisfaction, positive brand attitudes, patronage intentions and higher profit for non-store brands.

\section{METHODOLOGY}

To obtain an impartial perspective, a theoretical foundation was initially established through a literature review on shopping value dimensions. In addition, an empirical investigation using a quantitative research approach was conducted. The rationale for selecting a quantitative study was that it is cheaper, flexible and allows for replication of the research procedure, thus enhancing validity and reliability of research findings (Malhotra, 2010). Therefore, quantitative research surveys possess the objectivity and coherence that is necessary for identifying the fundamental idiosyncrasies' that underpin online shopping value research. 


\section{Sample Participants}

A non-probability purposive sampling method was used in the study to randomly select qualifying respondents. A sample size of 300 online shoppers was chosen for the study; consistent with that used by a number of scholars in similar studies (Cheng et al., 2009; Chen \& Dubinsky, 2003; Petrick, 2002; Childers et al., 2001). The target population comprised both male and female respondents of various age groups (18 years and older) who are actively involved in online purchases of non-store fashion brands from various South African based websites because it is believed that they can offer valuable contributions to the study (Churchill \& Iacobucci, 2002). To facilitate external validity of the study, only those users who had minimum experience ( $\geq 6$ months) with online purchases were included in the study. In addition, respondents younger than 18 and non-patrons of fashion retailer websites were considered non-eligible and therefore, excluded from the study.

\section{Measures And Instrumentation}

Owing to the lack of well-developed measures of the constructs within the context of online fashion brands, several multi-dimensional scales were consulted in the development of the questionnaire. Multi-dimensional scales were preferred over uni-dimensional scales since using the latter measure of value is awash with a plethora of limitations as it asserts that consumers have a shared meaning of value when in fact, different brand attributes may be considered to impact upon value perceptions (Petrick, 2002). In addition, uni-dimensional scales of perceived value lack clinical utility which is essential to provide direction regarding to how value may be improved (Woodruff, 1997). Therefore, viewing online shopping value as a multi-dimensional construct seemed to be more appropriate.

Section $\mathrm{A}$ of the instrument measured the hedonic shopping value dimension based on eleven items from the scale developed by Babin et al. (1994). Similarly, section B comprised of six items that measured utilitarian shopping value within an online context. Section $\mathrm{C}$ measured the engagement value of Internet shopping experiences using four items as suggested by Seraj (2012). In addition, other customer-value scales were referred to upon developing these sub-scales (Gallarza \& Saura, 2006; Li and Zhang, 2002; Sweeney \& Soutar, 2001; Sheth $e t$ al., 1991). Sections $\mathrm{D}$ and $\mathrm{E}$ measured the attitude (three items) and purchase intentions (3 items) constructs, respectively based on the studies of Koo and Ju (2008); O'Cass and Choy (2008) and Morris et al. (2002). The aforementioned sections were anchored on a five-point Likert scale ranging from strongly disagree (1) to strongly agree (5). In addition, Section $\mathrm{F}$ was included in the questionnaire to cover the demographic profile of the participants such as: gender, age, income levels, ethnic group, education levels, type of fashion websites patronised and frequency of participation. These questions were structured on a dichotomous, multiple choice and rankingorder closed-ended scales.

\section{Data Collection Procedure}

Primary data was collected from the respondents using a self-administered, multi-dimensional survey questionnaire. The researcher was involved in the fieldwork and played an active role in explaining the purpose of the study to the respondents. To ensure randomisation, data were collected at different times and days of the week. The respondents were given adequate time to complete the questionnaire and were assured of the participants' right to anonymity and confidentiality. Informed consent was observed by utilising an accompanying letter and opening statements on the questionnaire, citing the purpose, nature and legitimacy of the study. Voluntary participation was encouraged and the respondents were informed that they were able to withdraw from the study if they wished to do so (Creswell, 2009). Of the 300 questionnaires that were distributed, only 206 were returned and considered usable for the study giving a 69 per cent response rate.

\section{Scale Reliability}

Since the online shopping value instrument was adapted from several previous studies, it was necessary therefore, to verify the internal consistency (reliability) and validity among the sub-scales. According to Malhotra (2010), Cronbach's alpha values between 0.60 and 0.69 are deemed acceptable whilst values above 0.70 are regarded as satisfactory. Individual coefficient alpha values for the subscales ranged between 0.852 and 0.925 . 
Additionally, the Cronbach's alpha value for the entire scale was 0.820 revealing internal consistency and homogeneity of the study parameters.

\section{Validity Of The Study}

Prior to administration, the questionnaire was reviewed by two experts in the field of Fashion Marketing and e-business. This debriefing exercise enabled the researcher to refine the measuring instrument in terms of design, layout and wording, thereby ensuring that the instrument only comprised those questions that would validly answer the research hypotheses and achieve the research objectives (Sudman \& Blair, 1998). In addition, content validity was enhanced through pre-testing with a conveniently selected sample of 30 fashion shoppers. Members of the pre-test sample were excluded from the main survey to elude sampling bias. Exploratory factor analysis was conducted with a view to establish construct validity of the scale. The factor structure demonstrated absence of cross-loadings thus providing evidence of discriminant validity (items loading on each construct were theoretically dissimilar from those loading on the other constructs) as suggested by Mathwick and Malhotra (2002). Subsequently, the items loading on an individual construct were theoretically related to each other demonstrating high convergent validity (correspondence of items loading on one factor only). A stable three-factor structure was identified in line with the variables identified in the framework for the study. In addition, convergent validity was assessed through a computation of correlation coefficients as shown in Table 2. Positive and significant correlations were established on the three shopping value dimensions with both attitude and purchase intentions, further providing evidence of relationships and convergence. Similarly, the high alpha values on the scale items $(\geq 0.70)$ reflect the degree of cohesiveness among the scale items serving as an indirect indicator of convergent validity (Nunnally \& Bernstein, 1994). Predictive validity was assessed through linear regression analysis whereby the three online shopping value dimensions; namely; utilitarian value, hedonic value and engagement value, explained approximately 41 per cent of variance in attitude towards non-store fashion brands.

\section{DATA ANALYSIS}

\section{Sample Profile}

The respondents who participated in the survey were predominantly females ( 81 per cent; $n=167$ ) compared to males (19 per cent; $\mathrm{n}=39$ ). It is important to note that in past studies, females accounted for a higher percentage in terms of fashion-related studies (Cheng et al., 2009; Chen \& Dubinsky, 2003). The median age group of the consumer sample was between 19 years to 39 years $(n=161 ; 78$ per cent of the sample). Approximately 63 per cent of the sample $(n=130)$ were respondents of an African background while the other participants were of either Caucasian (21 per cent; $n=43$ ) or Asian descent (16 per cent; $n=33$ ). A majority of the respondents (51 per cent; $\mathrm{n}=105$ ) purported to spending at least an hour each week, visiting various online fashion web-stores either for information seeking, leisure or for pure shopping indulgence.

\section{Online Shopping Value Dimensions}

The Statistical Package for the Social Sciences (Version 21.0) was employed in the data analytical procedure. Principal Component Analysis (PCA) was performed as the default factor extraction method, while the rotation method was the Varimax method converged in six iterations. Selection of this orthogonal rotation method with Kaiser Normalization was aimed at producing factors that are uncorrelated, leading to high factor interpretability. Initially, the appropriateness of exploratory factor analysis (EFA) procedure was established through computing measures of sampling adequacy on the data set. The Kaiser- Meyer-Olkin (KMO) measure indicated a value of 0.887 (> 0.50) which exceeded the recommended value of .60 (Kaiser, 1970). The determinant of the Rmatrix was 0.001 (>.00001) in line with the recommendations by (Field, 2005) while the Bartlett's test of sphericity indicated a chi-square value value $\left(\chi^{2}\right)$ of 3947.025 suggesting that there was no multi- colinearity (very highly correlated variables) or singularity (perfectly correlated variables) problem in the data set. All this together supports the factorability of the component matrix.

Both over-extraction and under-extraction of factors retained for rotation can have deleterious effects on the results therefore, Kaiser's (1970) eigenvalues greater than one (>1) criteria, percentage of variance explained and 
the scree plot criterion guided the extraction of factors. Three data points were observed above the natural bend or break point along the scree plot curve leading to the final decision to retain three OSV dimensions. The total variance explained by the extracted factors was 78 per cent which according to Malhotra (2010) is satisfactory. These dimensions were labelled; (1) utilitarian value, (2) hedonic value and (3) engagement value. Psychometric properties of the extracted OSV factors as well as the mediating (attitude) and endogenous (e-purchase intentions) variables are reported on Table 1.

Table 1: Operational Definition Of Variables

\begin{tabular}{|c|c|c|c|}
\hline Dimension & $\begin{array}{c}\text { Cronbach } \\
\text { Alpha }\end{array}$ & Eigen Value & Description \\
\hline $\begin{array}{l}\text { Utilitarian } \\
\text { value }\end{array}$ & 0.852 & 8.502 & $\begin{array}{l}\text { Value derived from completing the online shopping task } \\
\text { efficiently and rationally, with minimum effort and also with a } \\
\text { view to saving time and resources (Scarpi, 2012). }\end{array}$ \\
\hline Hedonic value & 0.901 & 2.914 & $\begin{array}{l}\text { The entertaining, pleasure-ful and emotional assessment of the } \\
\text { online shopping experiences as opposed to being rational and } \\
\text { goal oriented (Rintamäki et al., 2006) }\end{array}$ \\
\hline $\begin{array}{c}\text { Engagement } \\
\text { value }\end{array}$ & 0.925 & 1.809 & $\begin{array}{l}\text { Value derived from consumers being able to build brand } \\
\text { communities and co-create knowledge about fashion brands } \\
\text { through contributing, customizing, rating, distributing and } \\
\text { interpreting non-store brand information via the e-tailer's } \\
\text { website and social networking pages (Humphreys, 2010) }\end{array}$ \\
\hline Attitude & & & $\begin{array}{l}\text { Positive or negative evaluations of consumers toward online or } \\
\text { non-store fashion brands (Ajzen, 1989) }\end{array}$ \\
\hline $\begin{array}{l}\text { e-Purchase } \\
\text { intentions }\end{array}$ & & & $\begin{array}{l}\text { A possible action taken by an individual to a specific object } \\
\text { (Kotler \& Keller, 2012). It is defined in this study as the } \\
\text { consumer's intention of using online websites to purchase non- } \\
\text { store fashion brands. This variable is measured by investigating } \\
\text { whether the Internet is an option for future buying activities and } \\
\text { also whether shoppers have the willingness to recommend the } \\
\text { Internet store to families and friends for buying fashion brands. }\end{array}$ \\
\hline
\end{tabular}

\section{Tests For Association (Strength And Direction)}

In order to examine the existence of relationships among the online shopping value dimensions with attitude, parametric correlations were computed using Pearson's correlation statistic $(r)$. This test statistic is used to describe the existence of a relationship amongst the constructs as well as the strength and direction of that association (Creswell, 2009). In addition, correlation analysis was performed with a view to describe the relationship between the attitude and the outcome variable, e-purchase intentions in the proposed framework. The results are reported in Table 2 of the study.

Table 2: Correlation Analysis: Shopping Value Dimensions With Attitude And E-Purchase Intentions

\begin{tabular}{|l|c|c|c|c|c|}
\hline \multicolumn{1}{|c|}{ Construct/Dimension } & Utilitarian & Hedonic & Engagement & Attitude & $\begin{array}{c}\text { e-Purchase } \\
\text { intentions }\end{array}$ \\
\hline Utilitarian value & 1 & & & & \\
\hline Hedonic value & $.251^{*}$ & 1 & & & \\
\hline Engagement value & .010 & $.108^{*}$ & 1 & & \\
\hline Attitude (ATT) & $.505^{*}$ & $.357^{* *}$ & $.459^{*}$ & 1 & 1 \\
\hline e-Purchase intentions (e-PI) & $.418^{* *}$ & $.383^{*}$ & $.291^{* *}$ & $.165^{*}$ & 3.724 \\
\hline Mean $(\bar{x})$ & 4.126 & 3.967 & 3.536 & 4.174 & .955 \\
\hline Standard Deviation (SD) & 1.063 & 1.037 & .873 & .083 \\
\hline
\end{tabular}

Since the relationship between the three online shopping value dimensions showed positive correlations with attitude and e-purchase intentions, stringent inferential examinations were conducted with a view to corroborate the assumptions of the linear regression models along with co-linearity diagnostics' checks. Firstly, the correlation matrix was examined for existence of multi co-linearity, i.e. if the predictor variables correlated too highly $(r>0.9)$ 
with each other (Field, 2005). None of the correlations in Table 2 reached a value of $r>0.9$ hence the data was considered suitable for linear regression analysis using the Enter method.

The first linear regression procedure was conducted with a view to establish the predictive relationship between the predictors (online shopping value dimensions) and their relative measurement response (attitude). The variance inflation factor (VIF) values in regression model one ranged between 1.113 and 3.922. This was deemed appropriate for multivariate data analysis as endorsed by Field (2005) who opined that VIF values that are greater than 10 show that the predictor variables are correlated among themselves hence co-linearity is a cause for concern. Similarly, tolerance levels that fall below 0.1 indicate serious co-linearity problems whereas tolerance values that are below 0.2 may potentially cause co-linearity problems. The tolerance statistics for the predictor variables ranged from 0.568 to 0.763 inferring that there was no co-linearity within the data set. The results are reported in Table 3 .

Table 3: Regression Model 1: Online Shopping Value Dimensions With Attitude

\begin{tabular}{|c|c|c|c|c|c|}
\hline \multirow{3}{*}{$\begin{array}{l}\text { Independent variables: } \\
\text { Online shopping value dimensions }\end{array}$} & \multicolumn{5}{|c|}{ Dependent variable: Attitude } \\
\hline & \multirow{2}{*}{$\begin{array}{c}\begin{array}{c}\text { Standardised } \\
\text { Coefficients }\end{array} \\
\text { Beta }\end{array}$} & \multirow[t]{2}{*}{$\mathbf{t}$} & \multirow{2}{*}{ Sig. } & \multicolumn{2}{|c|}{ Collinearity Statistics } \\
\hline & & & & Tolerance & VIF \\
\hline Utilitarian value & .513 & 8.030 & $.027 *$ & .696 & 3.922 \\
\hline Hedonic value & .544 & 7.509 & $.002 *$ & .763 & 1.113 \\
\hline Engagement value & .481 & 7.321 & $.000 * *$ & .568 & 2.628 \\
\hline \multicolumn{6}{|c|}{$\begin{array}{l}\text { Model 1 Summary: } \\
\mathrm{R}=0.635 \quad \mathrm{R}^{2}=0.403 \quad \text { Adjusted } \mathrm{R}^{2}=0.409 \quad \text { Std. error of the estimate }=.94386 \quad \mathrm{~F}=45.782 \\
\text { Significant at } 0.05 \text { level. }\end{array}$} \\
\hline
\end{tabular}

The regression analysis revealed that the three online shopping value dimensions (adjusted $\mathrm{R}^{2}=0.409$ ) explain approximately 41 per cent of the variance in the intentions to purchase fashion merchandise online. Furthermore, a large F statistic was obtained on the regression model at a value of $45.782(p=0.000)$ thus confirming the fitness of the regression model in measuring the predictive relationship between the dimensions and the attitude construct.

Strong and positive correlation coefficients were observed between the utilitarian value dimension with attitude $(r=0.505 ; \mathrm{p}<0.05)$. In addition, the utilitarian value dimension was ranked first on the factor mean score rankings ( $\bar{x}=4.126 ; \mathrm{SD}=1.063$ ) providing some indications of the level of agreeability regarding consumers' perceptions of the task-oriented nature of online fashion shopping. Moreover, the results of the regression analysis also reveal that utilitarianism is a statistically significant predictor of attitude $(\beta=0.513 ; t=8.030 ; p<0.05)$. Hence $\mathrm{H}_{1}$ which states that utilitarian value is positively related to attitudes toward non-store fashion brands is therefore supported. This is consistent with findings of Goldsmith and Goldsmith (2002) and Childers et al. (2001). However, studies of Kim and Forsythe (2008) allude to the virtual component of try-on e-tailing technology leading to the increased value perceptions of online shopping. The finding of this study presents important insights and implications for the South African fashion industry as well as both domestic and foreign investors. The positive relationship between utilitarian value and attitude suggests that shoppers evaluate non-store fashion shopping as providing high utilitarian value. Currently, if the system quality provided by an online shopping platform cannot provide consumers with perceived usefulness, consumers seeking utilitarian value may be affected leading to negative attitudes towards the online brands. For instance, some shoppers engage in online shopping behaviour for convenience and saving time (Scarpi, 2012). This means utilitarianism is a vital constituent of any online shopping experience as pointed out by Overby and Lee (2006).

Moderate and positive correlation coefficients were observed between the hedonic value dimension with attitude $(r=0.357 ; \mathrm{p}<0.01)$. Hedonic value $(\bar{x}=3.967 ; \mathrm{SD}=1.037)$ was ranked second on the factor mean score rankings. The results of the regression analysis revealed that hedonism is a statistically significant predictor of attitude $(\beta=0.544 ; t=7.509 ; p<0.01)$. Hence $\mathrm{H}_{2}$ which states that hedonic value is positively related to attitudes toward non-store fashion brands is therefore supported. This means that hedonism is an important component of online shopping experiences and will therefore determine consumer buying tendency. This study verified that online shopping value is created by pleasant, stimulating and novel websites that increase excitement and enjoyment during 
shopping (Koo \& Ju, 2010). Consequentially, these multi-sensory and emotive aspects of the consumer's experiences with non-store fashion brands will enhance positive attitudes and effectively behavioural intentions. The findings of this study are substantiated in literature by other scholars who argue that the aesthetic beauty derived from online browsing for fashion clothing coupled with the emotional rewards of enjoyment can increase the desire for purchasing non-store fashion brands (Byun \& Mann, 2011). This would ideally enhance the fashion retailer's website visitation frequency as the shoppers obtain entertainment and enjoyment that is directed by a desire for pleasure-shopping. Goldsmith and Goldsmith (2002) suggested that hedonic value is a psychological variable that influences an individual's decision to participate in online fashion shopping.

In terms of the engagement value dimension, strong and positive correlation coefficients were observed with attitude $(r=0.459 ; \mathrm{p}<0.05)$. The engagement value dimension $(\bar{x}=3.536 ; \mathrm{SD}=0.873)$ was ranked third on the factor mean score rankings. The results of the regression analysis also reveal that online engagement is a significant predictor of attitude toward non-store fashion brands $(\beta=0.481 ; t=7.321 ; p<0.001)$. Hence $\mathrm{H}_{3}$ which states that hedonic value is positively related to attitudes toward non-store fashion brands is therefore supported. These findings are in line with studies of Seringhaus (2005) and Seraj and Toker (2012) who assert that making the interaction collaborative adds further value to the shopping process and makes it more attractive. In the online experience allows all possible engagements on a product in an interactive way such that fashion retailers are able to provide a 'feel-like' atmosphere on the online store with a view to enhance the equity of their brand mix (Seraj, 2012). It is the interactivity that drives entertainment and social relationships on fashion web-stores and it is the closely knit tie toward the overall brand community and among the members of a network that produces social engagement value through interactions, which ultimately keeps its members together.

A second linear regression procedure was applied with a view to establish predictive validity between attitude (ATT) and e-purchase intentions (FI) variables. A large F statistic was also obtained on the regression model at a value of $39.206(p=0.000)$ thus confirming the fitness of the regression model in measuring the predictive relationship between attitude and e-purchase intentions. The VIF and tolerance value on this model were 1.000 and 0.564 , respectively; indicating acceptable levels for testing the relationship between the constructs. The results are reported in table 4.

Table 4: Regression Model 2: Attitude And E-Purchase Intentions

\begin{tabular}{|c|c|c|c|c|c|c|}
\hline \multirow{3}{*}{$\begin{array}{l}\text { Independent variables: } \\
\text { Attitude (ATT) }\end{array}$} & \multicolumn{6}{|c|}{ Dependent variable: e-Purchase Intentions (e-PI) } \\
\hline & \multirow{2}{*}{\multicolumn{2}{|c|}{$\begin{array}{c}\begin{array}{c}\text { Standardised } \\
\text { Coefficients }\end{array} \\
\text { Beta } \\
\end{array}$}} & \multirow{2}{*}{$\mathbf{T}$} & \multirow{2}{*}{ Sig } & \multicolumn{2}{|c|}{ Collinearity Statistics } \\
\hline & & & & & Tolerance & VIF \\
\hline Attitude & & 319 & 5.711 & $.000 * *$ & 0.564 & 1.000 \\
\hline \multicolumn{7}{|c|}{$\begin{array}{l}\text { Model } 2 \text { Summary: } \\
R=0.523 \quad R^{2}=0.273 \quad \text { Adjusted } R^{2}=0.277 \quad \text { Std. error of the estimate }=.95973 \quad F \text { change }=39.206 \text { Significant at } \\
0.05 \text { level. }\end{array}$} \\
\hline
\end{tabular}

The results of regression model 2 showed positive and statistically significant results between ATT and ePI ( $\beta=0.319 ; t=5.711 ; p<0.001$ ). Hence $\mathrm{H}_{4}$ which states that attitude (ATT) is positively related toward e-purchase intentions (e-PI) is therefore supported. Previous research also consistently reports positive interconnection between attitudes of e-retail shoppers and intentions to purchase online fashion brands that are not available in brick and mortar stores (Chen \& Dubinsky, 2003). However, weak but significant correlations were established between attitude and e-purchase intentions in the study $(r=0.165 ; \mathrm{p}<0.05)$. The regression analysis revealed that attitude explain approximately 28 per cent of the variance (adjusted $\mathrm{R}^{2}=0.277$ ) in shoppers' future intentions to actively purchase fashion clothing from online web stores. The other 72 per cent of the variance is purported to be a linkage between the attitude construct with other variables not discussed in this study such as word of mouth (Rowley, 2009) and willingness to pay a higher price for similar brands (Byun \& Mann, 2011). However, the extent to which these behavioural constructs translate into actual purchase decisions is still inconclusive and is yet to be explored further. 


\section{STRENGTHS, LIMITATIONS AND FURTHER RESEARCH}

The strength of the present study lies in its novelty through the validation of a conceptual framework that constitutes an important source of fresh knowledge on the underlying online shopping value dimensions among nonstore fashion brands. However, the study has a limitation in that its results are restricted to South African shoppers only. Furthermore, although the sample size of 206 respondents may have been adequate for statistical analysis, it may not present a true representation of the prominence of online fashion shopping, nationally. This implies that caution must be exercised when generalising the results to other geographical locations and upon deriving subsequent conclusions from this study. Therefore, a replication of this study to other cultures, utilising better sampling methods is warranted, in order to establish the robustness of the scale.

Value creation in online fashion shopping experiences is a very crucial question that still needs further research. More research may be conducted in different contexts to explore the linkages among the constructs used in this study. In addition, a randomised sample may be utilised with a view to confirm the efficacy of the framework; while employing more robust statistical techniques such as structural equation modelling with a view to model path relationship among the constructs.

\section{CONCLUSIONS AND RECOMMENDATIONS FOR THE STUDY}

This paper attempts to offer a more in-depth study of shoppers' behaviour on the electronic market. Moreover, this study proposed a conceptual framework to examine how the three dimensions of online shopping value affect attitude and ultimately, behavioural intention to purchase online fashion brands. Firstly, the analytical results showed that e-purchase intention was influenced to a limited extent by attitude towards non-store fashion brands. As such attitude is a weak determinant of e-shopping performance since some shoppers might still prefer to shop from the traditional stores. Secondly, online shopping value is a significant predictor of attitude towards online brands. Therefore, to enhance purchase intention, online stores should start improving shopping value by providing opportunities for utilitarianism, hedonism and social engagement for the shoppers. At the macro-level, identifying the online shopping value dimensions would provide fashion marketers with a basis for developing an integrated marketing strategy for their non-store brands. At the micro-level, e-retailers can tailor the identified dimensions for improving the online shopping experience among specific online market segments.

From a practical point of view, the entertaining and emotive nature of the online visit constitutes a central differentiation factor which impacts on attitude evaluations, intention to purchase as well as the willingness to visit the website and to share this experience with others. Thus, transactional website managers are compelled to give prominence toward creating holistic online shopping experiences. In a hyper-competitive environment, the utilitarian value dimension is the only way to differentiate a website. However, the effect of the hedonic value dimension provides an experiential process that buttresses the shopping experience by providing e-atmospherics that are more friendly, realistic and pleasureful. In addition, social presence through customer engagement also delivers a proximity feeling among the online shoppers. As such, the opportunities for knowledge co-creation and interactivity provide an opportunity for the shopper to be more committed during the online experience rather than a passive situation and therefore strengthens his/her choices of fashion brands. From a more theoretical point of view, the attitude variable is directly influenced by online shopping value and its role to predict e-purchase behaviour is reinforced. The findings, therefore, help us better understand the assortment of online shopping antecedents that are an essential ingredient when developing an extended differentiation strategy that is based on virtual platforms. In technology acceptance and adoption research, this study provided valuable insight into the acceptance and usage of new web 2.0 based technologies amongst a consumer setting.

\section{AUTHOR INFORMATION}

Nobukhosi Dlodlo is currently a lecturer and researcher in the Faculty of Management Sciences at the Vaal University of Technology, Gauteng, South Africa. She is an author of various peer-reviewed publications in various fields such as marketing, social psychology and business management. In addition, she has presented conference papers both nationally and internationally and is further involved in article reviews for several local journals. Her 
research interests include among others; online consumer behaviour, mobile communication technologies, ecommerce and social media marketing.

\section{REFERENCES}

1. Ali, M.H. (2007). Predicting the overall value of a leisure service: a survey of restaurant patrons in Pretoria. Thesis submitted for the degree Magister Commercii, University of Pretoria: South Africa.

2. Ajzen, I. (1989). Attitude structure and behavior. In A. R. Pratkanis, S. J. Breckler, \& A. G. Greenwald (Eds.), Attitude structure and function (pp. 241-274). Hillsdale, NJ: Lawrence Erlbaum Associates.

3. Babin, B.J., Darden, W.R. \& Griffin, M. (1994). Work and/or Fun: Measuring Hedonic and Utilitarian Shopping Value. The Journal of Consumer Research, 20(4) 644-656.

4. Balabanis, G., Reynolds, N. \& Simintiras, A. (2006). Bases of e-store loyalty: Perceived switching barriers and satisfaction. Journal of Business Research, 59(2) 214-224.

5. $\quad$ Bick, G., Brown, A.B. \& Abratt, R. (2004). Customer perceptions of the value delivered by retail banks in South Africa. The International Journal of Bank Marketing, 22(5) 300-318.

6. Boyd, D.M., \& Ellison, N.B. (2007). Social network sites: definition, history and scholarship. Journal of Computer-Mediated Communication, 13(1) 210-230.

7. Burke, R.R. (2002). Technology and the Customer Interface: What Consumers Want in the Physical and Virtual Store. Journal of the Academy of Marketing Science, 30(1) 411-432.

8. Byun, S-E. \& Mann, M. (2011). The influence of others: the impact of perceived human crowding on perceived competition, Emotions and Hedonic Shopping Value. Clothing and Textiles Research Journal, 29(4) 284-297.

9. Chaudhuri, A, Aboulnasr, K. \& Ligas, M. (2010). emotional responses on initial exposure to hedonic or utilitarian description of a radical innovation. Journal of Marketing Theory and Practice, 18(4) 339-59.

10. Chen, Z. \& Dubinsky, A.J. (2003). A conceptual model of perceived customer value in e-Commerce: A preliminary investigation. Psychology and Marketing, 20 (4) 323-347.

11. Cheng, J.M.S., Wang, E.S.T., Lin, J.Y.C. \& Vivek, S.D. (2009). Why do customers utilize the Internet as a retailing platform? Asia Pacific Journal of Marketing and Logistics, 21(1) 144-160.

12. Childers, T.L., Cristopher, C.L., Peck, J. \& Carson, S. (2001). Hedonic and utilitarian motivations for online retail shopping behaviour. Journal of Retailing, 77(1) 511-535.

13. Christianson, D. (2004). BEE 10 Years On. Enterprise, 186 (April), 104-108.

14. Churchill G.A. (Jr) Iacobucci D. (2002). Marketing research: Methodological foundations. $\left(8^{\text {th }}\right.$ ed), Fortworth: Harcourt College Publishers.

15. Creswell, J.W. (2009). Research design: Quantitative, qualitative and mixed methods approaches. $3^{\text {rd }}$ ed. Los Angeles: Sage Publishers.

16. Cronin, J.J.Jr., Brady, M.K. \& Hult, G.T.M. (2000). Assessing the effects of quality, value and customer satisfaction on consumer behavioral intentions in service environments. Journal of Retailing, 76(2) 193218.

17. Dichter, E. (1947). Psychology in market research. Harvard Business Review, 25(2) 432-443.

18. DeSarbo, W., Ebbes, P., Fong, D. \& Snow, C. (2010). Revisiting Customer Value Analysis in a Heterogeneous Market. Journal of Modelling in Management, 5 (1) 8-24.

19. Field A. (2005). Discovering statistics using SPSS. $2^{\text {nd }}$ ed. London: Sage Publishers.

20. Gallarza, M.G. \& Saura, I.G. (2006). Value dimensions, perceived value, satisfaction and loyalty: An investigation of university student's travel behaviour. Tourism Management, 27(3) 437-452.

21. Goldsmith, R.E. \& Goldsmith, E.B. (2002). Buying apparel over the Internet. Journal of Product and Brand Management, 11(2) 89-102.

22. Grewal, D. \& Levy, M. (2010). Marketing. $2^{\text {nd }}$ ed. Boston, Massachusetts: McGraw-Hill.

23. Holbrook, M.B. (1999). Introduction to consumer value: a framework for analysis and research. London: Routledge.

24. Holbrook, M.B. \& Hirschman, E.C. (1982). The experiential aspects of consumption: Consumer fantasies, feelings and fun. Journal of Marketing, 9(2) 132-140.

25. Humphreys, A. (2010). Co-producing Experience. In Medill on Media Engagement, Edward Malthouse, Abe Peck, editors. New York: Pine Forge Press.

26. Kaiser, H. F. (1970). A second generation little jiffy. Psychometrika, 35(1) 401-415. 
27. Kazakeviciute, A. \& Banyte, J. (2012). The relationship of consumers perceived hedonic value and behaviour. Inzinerine Ekonomika-Engineering Economics, 23(5) 532-540.

28. Kim, J. \& Forsythe, S. (2008). Adoption of virtual try-on technology for online apparel shopping, Journal Of Interactive Marketing, 22(1) 45-59.

29. Koo, D.M. \& Ju, S.H. (2010). The interactional effects of atmospherics and perceptual curiosity on emotions and online shopping intention. Computers in Human Behavior, 26(3) 377-388.

30. Kotler, P. \& Keller, K. (2012). Marketing Management. $14^{\text {th }}$ ed. New York: Prentice Hall Publishers.

31. Levy, M. \& Weitz, B.A. (2009). Retailing management. 7th ed. Boston, Massachusetts: McGraw-Hill.

32. Li, J.T., Kim, J.O. \& Lee, S.Y. (2009). An empirical examination of perceived retail crowding, emotions and retail outcomes. The Service Industries Journal, 29(5) 635-652.

33. Li, N. \& Zhang, P. (2002). Consumer online shopping attitudes and behavior: An assessment of research. Eighth Americas Conference on Information Systems, 508-517. USA.

34. Makholwa, A. (2011). Which retail model rules? Fin24.com, June 27. Research report on SA retailing. Retrieved from: http://www.fin24.com.

35. Malhotra, N.K. (2010). Marketing research: An applied orientation. 6th ed. New Jersey: Prentice Hall Publishers.

36. Mathwick, C., Malhotra, N.K. \& Rigdon, E. (2002). The effect of dynamic retail experiences on experiential perceptions of value: An Internet and catalogue comparison. Journal of Retailing, 78(1) 51-60.

37. McKinsey (2008). Building the Web 2.0 Enterprise. McKinsey Global Survey. The McKinsey Quarterly, June 2008.

38. Moodley, S. (2003). The challenge of E-Business for the South African apparel sector. Technovation, 23(1) 557-570.

39. Morris, J.D., Woo, C., Geason, J.A. \& Kim, J. (2002). The power of affect: predicting intention. Journal of Advertising Research, 42(3) 7-17.

40. Nunnally J.C. \& Bernstein I.H. (1994). Psychometric Theory. ( ${ }^{\text {rd }}$ ed), McGraw-Hill, New York.

41. O'Cass, A. \& Choy, E. 2008. Chinese generation Y consumers' involvement in fashion clothing. Journal of Product and Brand Management, 17 (5) 341-352.

42. Okonkwo, U. (2009). Sustaining the luxury brand on the Internet. Brand Management, 16(5/6) 302-310.

43. Overby, J. \& Lee, E. (2006). The effects of utilitarian and hedonic online shopping value on consumer preference and intentions. Journal of Business Research, 59(10/11) 1160-1166.

44. Petrick, J.F. (2002). Development of a multi-dimensional scale of measuring the perceived value of service. Journal of Leisure Research, 34(2) 119-134.

45. Planting, S. (2012). SA's online retail explosion. Retrieved from: http://www.moneyweb.co.za/moneywebsouth-africa/sas-online-retail-explosion?sn=2009\%20Detail.

46. Research and Markets. (2010). Clothing: South African industry guide 2010. Retrieved from: http://www.researchandmarkets.com.

47. Rintamäki, T., Kanto, A., Kuusela, H. \& Spence, M.T. (2006). Decomposing the value of department store shopping into utilitarian, hedonic and social dimensions. International Journal of Retail and Distribution Management, 34(1) 6-24.

48. Rowley, J. (2009). Online branding strategies of UK fashion retailers. Internet Research, 19(3): 348-369.

49. SAPA (2012). Online shopping on the rise in South Africa . (2012, April). TimesLive. Retrieved from: http://www.timeslive.co.za/scitech/2012/04/18/on-line-shopping-on-the-rise-in-south-africa-survey.

50. Scarpi, D. (2012). Work and fun on the internet: the effects of utilitarianism and hedonism online. Journal Interactive Marketing, 26 (2012) 53-67.

51. Seraj, M. (2012). We create, we connect, we respect and therefore we are: intellectual, social and cultural value in online communities. Journal of Interactive Marketing, 26 (1) 209-222.

52. Seraj, M. \& Toker, A. (2012). Social Network Citizenship. In Handbook of Research on Business Social Networking: Organizational. Managerial and Technological Dimensions. Maria Manuela Cruz-Cunha. Patricia Gonçalves, Nuno Lopes, Eva Maria Miranda, Goran D. Putnik, editors. IGI Global, 339-357.

53. Seringhaus, F.H.R. (2005). Selling Luxury Brands Online. Journal of Internet Commerce, 4(1) 1-25.

54. Seymour, K. (2012). The perceived value of scuba diving tourists at a marine destination. Thesis submitted for the degree Magister Artium in Tourism at the Potchefstroom Campus. North-West University. South Africa. 
55. Sheth, J., Newman, B. \& Gross, B. (1991). Why we buy what we buy: A theory of consumption values. Journal of Business Research, 22 (March) 159-170.

56. Siddiqui, N., McColl, J., O'Malley, A. \& Birtwistle, G. (2003). Retailer and consumer perceptions of online fashion retailers: Web site design issues. Journal of Fashion Marketing and Management, 7(4) 345-355.

57. Statistics South Africa. (2010). Report on retail trade industry. Retrieved from: http://www.statssa.gov.sa/publications.html.

58. Strydom, E. (2011). A multidimensional customer value model for the high fashion retail industry. Dissertation submitted for the requirements of the degree PHD Marketing Management, University of Johannesburg: South Africa.

59. Sudman S. \& Blair E. (1998). Marketing research: A problem solving approach, Boston: McGraw Hill.

60. Sweeney, J.C. \& Soutar, G.N. (2001). Consumer perceived value: the development of a multiple item scale. Journal of Retailing, 77(2) 203-220.

61. Swait, J. \& Sweeney, J.C. (2000). Perceived value and its impact on choice behaviour in a retail setting. Journal of Retailing and Consumer Services, 7(1) 77-88.

62. Terblanche, N.S. \& Boshoff, C. (2010). Quality, value, satisfaction and loyalty amongst race groups: A study of customers in the South African fast food industry. South African Journal of Business Management, 41(1) $1-9$.

63. Van derHeijden, H., Verhagen, T. \& Creemers, M. (2003). Understanding online purchase intentions: contributions from technology and trust perspectives. European Journal of Information Systems, 12(1) 4148.

64. Westbrook, R. \& Black, W. (1985). A motivation-based shopper typology. Journal of Retailing, 61(1) 78103.

65. Woodruff, R.B. (1997). Consumer value: the next source of competitive advantage. Journal of the Academy of Marketing Science, 25(2) 139-153.

66. Zeithaml, V.A. (1988). Consumer perceptions of price, quality and value: A means end model and synthesis of evidence. Journal of Marketing, 52(3) 2-22. 


\section{NOTES}

